\title{
İşletmelerin Sosyal Medya Hesapları Üzerinden Kurmuş Oldukları İletişiminin Marka Değeri Üzerine Etkisi
}

\author{
Onur Keşapl1* \\ Uşak Üniversitesi, İletişim Fakültesi, Uşak. \\ $\ddot{O} z$ \\ Günümüzde sosyal medya işletmelere pazarlama ve markalama stratejileri ve planları \\ açısından önemli firsatlar sunmaktadır. Bu çalışmada işletmelerin sosyal medya hesapları \\ üzerinden müşterileri ile kurmuş oldukları iletişiminin marka değeri üzerine etkisi ölçülmeye \\ çalışılmıştır. Sosyal medya mecrası olarak seçilen Facebook da havayolu işletmesinin Facebook \\ üzerinden müşterileri ile kurmuş olduğu iletişiminin marka farkındalığı, algılanan kalite ve marka \\ bağlllı̆̆ına olan etkisi belirlenmeye çalışılmıştır. Araştırmanın katılımcıları, Facebook üyesi olan \\ ve sosyal paylaşım sitelerinde markaların kullanıcılarıdır, veriler eposta yolu anket yöntemi \\ kullamılarak elde edilmiştir. Araştırmaların sonucuna göre markaların sosyal medya \\ hesaplarından müşterileri ile iletişime geçmelerinin markalarm değerine etkili olduğu ortaya \\ çıkmıştır.
}

Anahtar kelimeler: Sosyal Medya, Marka Değeri, Facebook, Marka İletişimi

\section{The Effect of Social Media Interaction of Companies on Brand Values}

\section{Abstract}

Today, social media provides important opportunities to companies for advertising and marketing strategies and plans. This study attempts to measure the effects of the company and customer interaction via social media, on brand value. This study, through the selected social medium Facebook, attemtps to assess the effect of the interaction between an airline company and its customers on brand awareness, perceived quality and brand loyalty. Participants of this study are members of Facebook and demonstrate their use of these brands at social posting sites. The data has been collected through a survey via email. According to the findings, the social media interaction between companies and customers has an effect on brand values.

Keywords: Social Media, Brand Value, Facebook, Brand Communication.

\section{Gíriş}

Değişen ve sürekli yenilenen dünya ile beraber pazarlama stratejilerinde iletişimin önemi her geçen gün artmaktadır. Önceleri pazarlama stratejileri daha geleneksel yüz yüze iletişime dayalı bir düzen içerisindeydi. Günümüzde teknolojinin gelişmesi, internetin tüm dünyayı kapsaması ile beraber dünya küresel büyüklükte bir köy haline gelmiştir. Bu küresel büyüklükteki köy içerisinde işletmeler kendi farkındalıklarını oluşturmak ve sürekli daha da şiddetlenen rekabet ortamında galip gelmek için pazarlama stratejilerine ihtiyaç duymaktadır.

Özellikle sosyal medya kullanımının artması ile birlikte yeni bir pazarlama mecrası oraya çıtı. İşletmeler bu rekabet ortamında farkındalık çalışmalarına önem vermeye başlamaktadır. Tüketiciler bir markayı tanıyor ve onun hakkında bilgi sahibi ise, ürünü satın alma kararı vermek için çok fazla düşünme ve bilgi işleme süreci ile uğraşmak zorunda kalmamaktadır. İşletmelerin kendilerini tanıtmak için sürekli olarak 
kuracakları iletişimin önemi bir kez daha gözler önüne serilmektedir. Dolayısıyla, sosyal paylaşım sitelerini oldukça etkili bir ortam olarak görmenin ve bu mecralardan maksimum düzeyde yararlanmanın işletmeler açısından büyük getirileri olmaktadır. Twitter, bloglar, Facebook, Flickr gibi insanların bir araya geldiği sosyal medya ortamlarında, işletmelerden ve ürünlerden bahsedilmektedir. Bu, işletmelerin yaptığ bazı çalışmalar için direkt cevap olmayabilir ama yaptıkları tüm çalışmalar için bir cevaptır. Buradan hareketle bu çalışma işletmelerin sosyal medyada müşterileri ile kurmuş oldukları iletişimin marka değerine etkisi olup olmadığı ölçümlenmeye çalışılmıştır.

Çalışmada öncelikle sosyal medya, pazarlama, marka değeri ve unsurları hakkında teorik bilgiler verilmekte, daha sonra ise konuya ilişkin olarak yapılan saha araştırmasının analiz ve bulguları sunulmaktadır.

\section{TEORIKK ÇERÇEVE}

\subsection{Sosyal Medya ve Pazarlama İlişkisi}

Önceleri kişilerin iletişim ortamları son derece kısıtlı ve daha çok yüz yüze iletişime dayalıydı. Özellikle 2000'li yıllardan sonra internetin yaygınlaşması, teknolojik gelişmeler yeni iletişim ortamları oluşturmuştur. Oluşan bu iletişim ortamlarına farklı farklı isimler verilmekte ve bu iletişim ortamlarının kullanımı sürekli artmaktadır. Son zamanlarda sosyal medya tercih edilen ve kullanılan iletişim ortamlarının başında gelmektedir. Bu ortamın oluşması ile birlikte bireylerin birbirleri ile olan etkileşimi daha da artmaktadır (Bruhn vd., 2012: 773). Kişilerin sıkça vakit geçirdiği ve birbirleri ile sürekli olarak etkileşim içerisinde olduğu bu ortam beraberinde birçok tanımı meydana getirdi. Bu bağlamda sosyal medya yeni nesil web teknolojilerinin getirdiği kullanıcı kolaylığı ve iletişim hızıyla yakalanan eş zamanlı bilgi paylaşımının takip edildiği dijital platform olarak tanımlanabilir (Li ve Bernoff, 2011: 46).

Tanımda da belirtildiği gibi sosyal medya iletişim hızıyla yakalanan eş zamanlı bilgi paylaşımının takip edildiği ve sürekli olarak iletişimin gerçekleştiği bir mecradır. İletişim ve etkileşimin olması işletmelerin rekabet ortamı içerisinde bu ortamlardan yararlanması gereğini güçlendirmiştir. Bu noktada pazarlama bölümü çalışanlarının tutundurma faaliyetleri çerçevesinde en çok önem verdikleri konulardan biri potansiyel/mevcut müşterileri ile yer ve zaman kısıtları olmadan iletişim kurabilmek ve bilinirliklerini arttırmak (Kaplan ve Haenlein, 2012: 28) olduğundan sosyal medya bu bağlamda tabiri caizse bulunmaz bir Hint kumaşı kıymetindedir. Çünkü neredeyse bütün işletmeler sosyal medyayı pazarlama stratejilerini oluştururken tercih etmektedir. Bu tercihte sosyal medya kullanıcı sayısındaki artış etkili olmaktadır. Bununla beraber geleneksel pazarlamada iletişim maliyetleri sosyal medyadaki iletişim maliyetlerine göre daha külfetli olduğundan sosyal medya işletmeler ve pazarlama uzmanları acısından bulunmaz bir nimet olarak atfedilmektedir (Can ve Çetin, 2017: 32). Ayrıca sosyal medyanın hedef kitleye ulaşma ve hedef kitlenin genişliği açısından da ayrı bir öneme sahiptir, mevcut ve potansiyel hedef kitleye ulaşmada ve işletme ile 
hedef kitle arasında var olan ilişkileri geliştirmede sosyal medya büyük bir öneme sahiptir.

\subsection{Sosyal Medya ve Marka İlişkisi}

İşletmeler var olan marka imajlarını oluşturmak ve bu imajı korumak için tüm iletişim yöntemlerine başvurmaktadır. Bu bağlamda yukarıdaki tanımdan yola çıkarak eş zamanlı bilgi paylaşımının getirilmesi sosyal medyayı işletmelerin kullanacağ iletişim platformu olarak tanımlanabilir (Wang ve Li, 2012: 147). Bu iletişim platformu içerisinde işletmeler isim, slogan ve sembolleri aracılığı ile sosyal medyada rakiplerinden ayrılmak istemektedir. Bu iletişim platformu içerisinde işletmeler mevcut marka değerlerini, imajlarını sosyal medya ortamında gerçekleştireceği iletişim stratejileri ile daha da kuvvetlendirmeyi amaçlamaktadır (Villarejo-Ramos ve SánchezFranco, 2005: 434).

$\mathrm{Bu}$ bağlamda markalaşma ve mevcut marka algısını güçlendirmek için iletişimde marka yararı odaklı duygusal anlatımlar önem kazanmaktadır. Bu duygusal yararlı anlatımı oluşturmak için ise var olan sosyal medya ortamından yararlanmak son derece hayati öneme sahiptir. İşletmelerin müşterileri ile sürekli olarak kuracakları iletişim markaya olan bağlılığı arttıracak ve aralarındaki duygusal ilişkiyi güçlendirecektir. Bu bağlamda sosyal medyanın müşterilere ulaşmada çok cazip gelmesi marka ile sosyal medya arasındaki ilişkiyi güçlendirmektedir (Pira vd., 2005: 66).

\subsection{Marka Değeri}

Dünyada her yıl binlerce marka piyasaya girmekte ve bunlardan yalnızca bir kaçı pazarda kalmayı başarmaktadır. Bu sebepten pazara girmekten ziyade marka alg1sı oluşturulması çok güç olmaktadır. İşletmelerin de en temel amacı bu zor süreç içerisinde marka değerlerini oluşturmaktır (Christodoulides ve de Chernatony, 2010: 45). Bu bağlamda marka değeri hakkında yapılan bazı tanımları ele alacağız:

Marka değeri; markanın işletme ve müşteriler için sağladığı yararların bütünü olarak tanımlanabilir (Bambauer-Sachse ve Mangold, 2011: 39). Marka değeri; bir markayla, markanın adıyla, simgesiyle bağlantılı ve bir firmaya veya firmanın müşterilerine ürün ve hizmet yoluyla sağlanan değeri arttıran veya azaltan aktiviteler ve taahhütler bütünüdür. Bir anlamda markaya yapılmış olan pazarlama yatırımları sonucunda markayla özdeşleşmiş değerler toplamıdır (Kırdal, 2005: 24).

Bu noktada düşünüldüğünde marka değeri, hem işletme hem de müşteri bazlı bir süreçtir. Çünkü pazardaki rekabet ürün savaşlarından çok marka savaşlarında gerçekleştiği gayet aşikârdır (Can, 2016: 125). Marka değerini, işletmelere olan değeri arttıran ve azaltan bir aktivite olarak ele aldığımızda ise genel anlamda bu değeri azaltmanın ve artırmanın en etkili çözümü iletişim faaliyetleridir. İnsanın bilmediğinden korkması göz önünde tutulduğunda markayı bilmek istemesi gayet açıktır. Bu sebepten ötürü marka değerine etki eden unsurlar; marka bağlılığı, marka farkındalığı ve algılanan kalite olarak sıralanabilir (Mackay, 2001: 45). 


\subsection{Marka bağlılığı}

Literatürde bağlılığın herkes tarafından kabul edilen ortak bir tanımı yoktur. Yapılan çalışmalarda, çoğunlukla bağlılık; tüketicinin tüm rakip pazarlama faaliyetlerine rağmen aynı markayı satın alması şeklinde tanımlanmaktadır (Aaker, 1996: 105)

Bu bağlamda ele alındığında bağlılık değişen koşullar olmasına rağmen aynı markanın tercih etmesi olarak görülebilir. Bunun yanı sıra müşteriler markaya olan bağlılıklarını çeşitli davranışlar sergileyip göstermektedir (Gil vd., 2007: 191). Örneğin, BMW kullanıcısının anahtarlık, çakmak vb. aksesuarlarında yine bağlı olduğu markayı seçmesinde olduğu gibi müşterilerin bu bağlılıkları göstermesindeki en temel neden hiç kuşkusuz bağlı olduğu işletmeye yönelik memnuniyetidir (Brodie vd., 2013: 17). Bununla beraber tüm rakip pazarlama faaliyetlerine karşıllı işletmenin herhangi bir pazarlama faaliyetini yürütmemesi tüketicilerin var olan bağlılığını ciddi noktada zedelemektedir. Bu sebepten ötürü tanımda eksik kalan bazı kısımlar bulunmaktadır (Raggio ve Leone, 2007: 385). Tanımdan hareket ile yapılacak daha kapsamlı tanım ise;

İşletmelerin var olan değişimlere ayak uydurarak, müşterileri ile sürekli olarak aralarında kurmuş oldukları bağı ve tercihi marka bağlılığı olarak ifade edebiliriz. Tanımdan hareketle bazı özellikler üzerinde durulması gerekmektedir. Bu bağlamda tanımda var olan süreklilik ve tercih kelimeleri üzerinde durduğumuzda, işletmeler ile müşteriler arasında bir bağlılıktan söz etmemiz için öncelikle aralarında süreklilik olması gerekmektedir; müşteri her koşullarda yine aynı işletmeyi tercih etmelidir. Burada tercih ise davranış olarak atfedilmiştir. Bu sebepten tercih, müşterinin her daim tüketim davranışını işletmeden yana kullanmasıdır (Shum, 2004:247).

\subsection{Marka Farkındalığı}

Markanın temel tanınırlığı farkındalık yaratılarak sağlanabilir. Bu sebeple markanın tam olarak meydana gelmesi ancak tüketiciler tarafından fark edilebilmesi ile mümkündür. Farkındalık, markanın tüketicinin zihninde yarattığı etkiyi ifade etmektedir (Aaker, 1996: 7). Marka farkındalığ bir marka hakkında sahip olduğu iyi veya kötü bilgiler toplamından oluşmaktadır (Palmatier vd., 2007:189). Başka bir tanıma göre ise marka farkındalığı markadan haberdar olma, tüketicinin hafızasında markanın rakiplerle karşılaştırmalı olarak aldığ yerdir (Pira vd., 2005: 88).

Bu tanımları göz önüne aldığımızda marka farkındalığına dair birçok özellik söylenmiştir. Fark edilmenin en güzel yolu iletişim faaliyetleridir. Fark edilmek ve bilinmek işletmeye karşı olan tutumu ciddi noktada etkileyeceği için bunların göz önüne alınması uygun olabilir (Ha vd., 2011:681). Markanın temel tanınırlığı farkındalık yaratılarak sağlanabilir. Markanın inşa edilmesi için temel olan değişkenlerin başında farkındalık gelmektedir. Marka farkındalığı, marka tanınırlığı ve marka hatırlanma başarımını içermektedir (Keller, 2009:149). 


\subsection{Algılanan Kalite}

Çevredeki nesnelere, ilişkin olarak alınan duyumsal bilgi algılamadır. Algılama bu bağlamda değerlendirildiğinde bireyin her türlü soyut ve somut nesnelere karşı vermiş olduğu tepkilerin fizyolojik bir yanıdır da denilebilir (İnceoğlu, 2011: 86). Tanımdan hareket ile müşterinin markaya karşı vermiş olduğu tepki de fizyolojik olmaktadır. Bu sebepten ötürü marka oluşumunda öncelikle kalite düşüncesi yaratılmalıdır. $\mathrm{Bu}$ ise müşterinin istediği nitelikleri karşılama yeteneği olarak algilanmaktadır (Muñiz ve Schau, 2007: 39).

Kalite algısı, müşteriden müşteriye farklılık gösterebilmektedir. Bazıları kaliteyi, söz konusu ürünün fiziksel özellikleri, sağlamlık, amaca uygunluk olarak değerlendirirken, bazıları da, fiyatın yüksek oluşu olarak değerlendirmektedir (Bazanbaş, 2013: 13). Ancak algılamanın öncelikli olarak önemli olan yanı, sosyal ve psikolojik bir olgu olduğu ve dış müdahalelerle kontrol edilip yönlendirilmesidir (İnceoğlu, 2011 :87).

$\mathrm{Bu}$ bağlamda ele alındığında algılanan kalite, işletmenin mevcut ürünlerinin kalitesini, müşterisine karşı nasıl oluşturduğudur. Bununla birlikte, kalite konusunda önemli olan bir diğer unsur, müşterilerin kalite algılamalarının sadece ürün ya da hizmetlere bağlı olmamasıdır. Müşteriler, işletme ile aralarındaki ilişkinin kalitesine de önem vermektedirler (Taşkın, 2005: 56).

\section{ISSLETMELERIN SOSYAL MEDYA HESAPLARI ÜZERINNDEN KURMUŞ OLDUKLARI İLETIŞIMIIN, MARKA DEĞERI ÜZERINNE ETKISSINIIN OLUP OLMADIĞINI TESPIT ETMEYE YÖNELIKK BİR ARAŞTIRMA}

\subsection{Araştırmanın Amacı, Kapsamı ve Kısıtları}

Araştırmada işletmelerin sosyal medya hesapları üzerinden müşterileri ile kurmuş oldukları iletişimin marka değeri üzerine etkisi olup olmadığı araştırmak amaçlanmıştır.

Araştırmanın kapsamını; uygulanan saha itibari ile sosyal medya hesapları olan ve $X$ Hava Yolları Facebook sayfasını beğenen sosyal medya kullanıcıları oluşturmaktadır. Çalışmada sosyal medya hesapları olma ve X Hava Yolları sayfasını beğenme şartı aranmıştır. Bu şartların aranma sebebi ise çalışmada elde edilecek verilerin daha sağlıklı sonuçlar vermesi içindir. Araştırmanın en önemli kısıtlılığı, zaman ve maddi kaynak yetersizliği olmuştur. Bununla beraber veri toplama sürecinde ciddi derecede zaman ve emek kaybı ortaya çıkmıştır.

\subsection{Araştırmanın modeli}

Araştırmanın amacı doğrultusunda oluşturulan araştırma modeli aşağıdadır. 


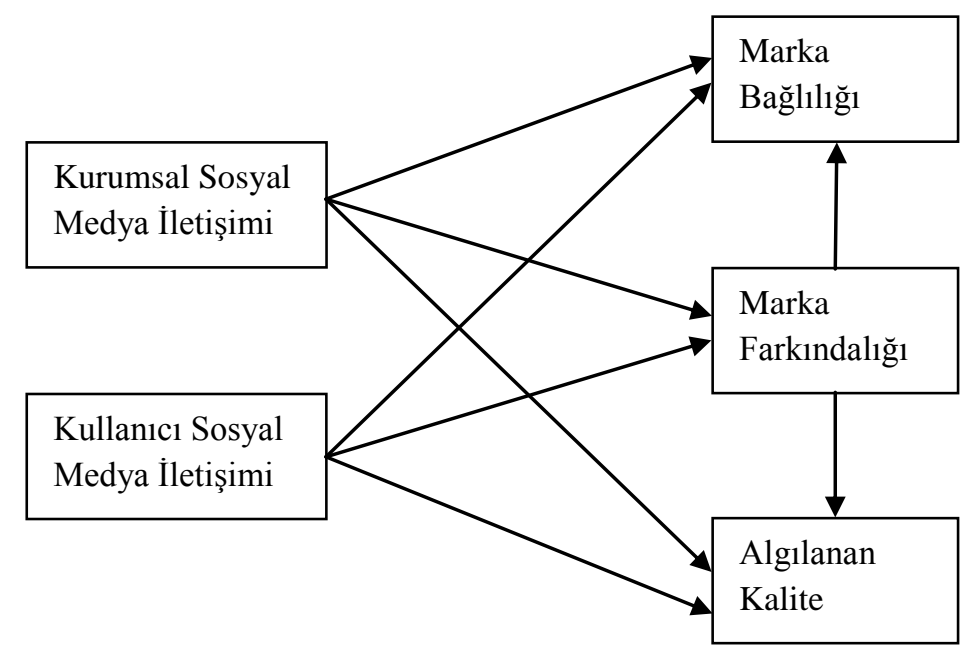

Şekil 1. Araştırmanın Modeli

Araştırma modeli Şekil 1'de gösterilmiştir. Model, Schivinski ve Dabrowski'nin (2014) çalışması esas alınarak hazırlanmıştır. Söz konusu çalışmada, marka farkındalığı, marka bağlılı̆̆ını ve algılanan kaliteyi, bununla beraber işletmeler tarafından oluşturulan sosyal medya iletişimi ise algılanan kaliteye, marka farkındalığına ve marka bağlılığına etki etmektedir. Ayrıca kullanıcılar tarafından oluşturulan sosyal medya iletişiminin de marka bağlılığına, marka farkındalığına ve algılanan kaliteye etki ettiği gözlemlenmiştir.

\subsection{Araştırma hipotezleri}

Araştırma amacı ve modeli doğrultusunda hipotezler şu şekilde belirlenmiştir:

$\mathrm{H}_{1}:$ Isşletme tarafından oluşturulan sosyal medya iletişimi marka bağlılığını etkilemektedir.

$\mathrm{H}_{2}$ :İşletme tarafından oluşturulan sosyal medya iletişimi marka farkındalığını etkilemektedir.

$\mathrm{H}_{3}:$ Isşletme tarafından oluşturulan sosyal medya iletişimi algılanan kaliteyi etkilemektedir.

$\mathrm{H}_{4}$ :Müşteri tarafından oluşturulan sosyal medya iletişimi marka bağlılı̆̆ını etkilemektedir.

H5:Müşteri tarafından oluşturulan sosyal medya iletişimi marka farkındalığını etkilemektedir.

H6:Müşteri tarafindan oluşturulan sosyal medya iletişimi algılanan kaliteyi etkilemektedir.

H7:Marka farkındalığı marka bağlılığını etkilemektedir.

H8:Marka farkındalığı algılanan kaliteyi etkilemektedir. 


\subsection{Araştırmanın Metodolojisi}

\subsection{1. Ön Çalışma}

Türkiye merkezli 11 havayolu (Türk Hava Yolları, SunExpress, Pegasus, Anadolujet, Onur Air, AtlasGlobal, Borajet, Corendon Hava Yolları, Freebird Hava Yolları, Tailwind Airlines, Fly Air) işletmesi mevcuttur. Araştırma için kesin anket formu hazırlanıp veri toplanmasına geçilmeden önce araştırmada kullanılacak havayolları işletmesini belirlemek için 30 tüketiciye seyahatlerinde tercih ettikleri havayolu işletmesi sorulmuş ve A havayolunun 11 kişi, B havayolunun 8 kişi, C havayolunun 5, D havayolunun 4 ve E havayolunun 2 kişi tarafından tercih edildiği belirtilmiştir. Bu durumda A havayolu araştırmanın kapsamına alınmıştır. Daha sonra araştırmada kullanılacak anket formu hazırlanmış ancak veri toplama aşamasına geçilmeden önce 20 müşterinin anketle ilgili görüşleri alınmış ve görüşler doğrultusunda anlaşılmayan 3 ifade düzeltilip anket formuna son şekli verilmiştir.

\subsection{2. Örnekleme süreci}

Araştırmanın ana kütlesini sosyal medya kullanıcıları oluşturmaktadır. Örneklem yöntemi olarak kolayda örnekleme yöntemi benimsenmiştir. Ana kütlenin standart sapmasının bilinmediği ve \%5 hata payı ile araştırmanın örneklem büyüklügü $\mathrm{n}=384$ olarak benimsenmiştir ve hatalı ve eksik doldurulma ihtimaline karşılık 400 anket uygulanmıştır.

\subsubsection{Veri Toplama Yöntem ve Aracı}

Araştırma veri toplama yöntemi olarak anket tekniği uygulanmıştır. Anket formunda 2 grup soruya yer verilmiştir. Birinci grup sorular cinsiyet, medeni durum, yaş, eğitim, gelir ve meslekten oluşan ve cevaplayıcıların demografik özelliklerini ortaya koyan, ikinci grup sorular ise, işletme kaynaklı iletişim, müşteri kaynaklı iletişim, marka bağlılığı, marka çağrışımı ve marka farkındalığından oluşmaktadır. Cevapların alınmasında 5'li Likert ölçeği (5= Tamamen katılıyorum; 1= Kesinlikle katılmıyorum) kullanılmıştır. Veriler SPSS 13,0 ve LISREL 8.51 istatistik programları yardımıyla analiz edilmiştir. Verilerin analizinde, doğrulayıcı faktör analizi, yapısal eşitlik analizi, frekans dağılımları, ortalamalar ve standart sapma kullanılmıştır.

\subsection{Verilerin Analizleri}

\subsubsection{Demografik Özellikler}

Tablo 1'de araştırmaya katılan cevaplayıcıların demografik ve ekonomik özellikleri gösterilmiştir. 
Tablo 1. Cevaplayıcıların Demografik ve Ekonomik Özellikleri

\begin{tabular}{|c|c|c|c|c|c|}
\hline Cinsiyet & Frekans & Yüzde & Medeni hal & Frekans & Yüzde \\
\hline Kadın & 158 & 39.5 & Evli & 230 & 57.5 \\
\hline Erkek & 242 & 60.5 & bekar & 170 & 42.5 \\
\hline Yaş & Frekans & Yüzde & Eğitim & Frekans & Yüzde \\
\hline $18-24$ & 68 & 17.0 & İlköğretim & 47 & 11.8 \\
\hline $25-33$ & 102 & 25.5 & Lise & 98 & 24.5 \\
\hline $34-42$ & 111 & 27.8 & Önlisans & 104 & 26.0 \\
\hline $43-51$ & 68 & 17.0 & Lisans & 99 & 24.7 \\
\hline 51 ve üzeri & 51 & 12.7 & Lisansüstü & 52 & 13.0 \\
\hline Meslek & Frekans & Yüzde & Gelir (TL) & Frekans & Yüzde \\
\hline Öğrenci & 23 & 5.8 & $0-1000$ & 23 & 5.7 \\
\hline Evhanımı & 63 & 15.7 & $1001-3000$ & 148 & 37.0 \\
\hline İşçi & 70 & 17.5 & $3001-5000$ & 91 & 22.8 \\
\hline Memur & 117 & 29.3 & $5001-7000$ & 108 & 27.0 \\
\hline Esnaf & 86 & 21.5 & 7000 ve üzeri & 30 & 7.5 \\
\hline Serbest meslek & 41 & 10.2 & & & \\
\hline Toplam & 400 & 100.0 & Toplam & 400 & 100.0 \\
\hline
\end{tabular}

Araştırmaya katılan katılımcıların \% 60.5 kısmını erkeklerden oluştururken \%39.5 kısmını kadınlar oluşturmaktadır. Bunun yanı sıra araştırmaya katılan katılımcıların \%57.5'inin evli olduğu tespit edilmiştir. Ayrıca katılımcıların yaş aralıkları daha çok 32-42 yaş aralığı ile \%27.8'lik paya sahiptir. Katılımcıların eğitim durumlarına baktığımızda büyük çoğunluğun önlisans ve lisans mezunu oldukları tespit edilmiştir. Araştırmaya katılan katılımcıların çoğunun gelir düzeylerine baktığımızda 1001-7000 TL aralığında olduğu görülmektedir. Katılımcıların meslek gruplarında en fazla paya sahip olan \%29.3'lük pay ile memurlardır.

\subsubsection{Cevaplayıcıların Marka İletişimine Yönelik Düşüncelerinin Belirlenmesi}

Cevaplayıcılara ve algılanan kalite hakkındaki algı ve tutumları ile ilgili çeşitli ifadeler sunulmuş ve değerlendirmeleri istenmiştir. Bu değerlendirmeye ilişkin ortalama ve standart sapma değerleri Tablo 2'de gösterilmiştir. 
Tablo 2. Cevaplayıcıların Araştırmada Yer Alan Değişkenlerin İfadelerine Karşı Algı ve Tutumları

\begin{tabular}{|c|c|c|}
\hline Değişkenler ve İfadeleri & $\begin{array}{c}\text { Aritmetik } \\
\text { Ortalama }\end{array}$ & $\begin{array}{c}\text { Standart } \\
\text { Sapma }\end{array}$ \\
\hline \multicolumn{3}{|l|}{ Kurum Kaynaklı İletişim $(\alpha=0.814)$} \\
\hline X Hava Yollarının Facebook'taki kurumsal iletişiminden memnunum. & 4,02 & 1,29 \\
\hline $\begin{array}{l}\text { X Hava Yollarının Facebook'taki kurumsal iletişimi benim } \\
\text { beklentilerimi karşılamaktadır. }\end{array}$ & 3,54 & 1,26 \\
\hline $\begin{array}{l}\text { X Hava Yollarının Facebook'taki kurumsal iletişimi oldukça ilgi } \\
\text { çekicidir. }\end{array}$ & 3,96 & 1,15 \\
\hline $\begin{array}{l}\text { X Hava Yollarının Facebook'taki kurumsal iletişimi diğer havayolu } \\
\text { işletmeleriyle karşılaştırıldığında onlardan daha iyidir }\end{array}$ & 3,96 & 1,02 \\
\hline \multicolumn{3}{|l|}{ Müşteri Kaynaklı İletişim $(\alpha=0.801)$} \\
\hline $\begin{array}{l}\text { X Hava Yolları hakkında diğer kullanıcılar tarafından sosyal medyada } \\
\text { yapılan paylaşımlardan memnunum. }\end{array}$ & 3,08 & 0,99 \\
\hline $\begin{array}{l}\text { X Hava Yolları hakkında diğer kullanıcılar tarafından sosyal medyada } \\
\text { yapılan paylaşımlar benim beklentilerimi karşılamaktadır. }\end{array}$ & 3,03 & 0,90 \\
\hline $\begin{array}{l}\text { X Hava Yolları hakkında diğer kullanıcılar tarafından sosyal medyada } \\
\text { yapılan paylaşımlar oldukça ilgi çekicidir. }\end{array}$ & 3,25 & 0,90 \\
\hline $\begin{array}{l}\text { X Hava Yolları hakkında diğer kullanıcılar tarafından sosyal medyada } \\
\text { yapılan paylaşımlar diğer havayolları işletmeleriyle karşılaştırıldığında } \\
\text { onlardan daha iyidir. }\end{array}$ & 3,56 & 0,94 \\
\hline \multicolumn{3}{|l|}{ Marka Farkındalığı $(\alpha=0.844)$} \\
\hline X Hava Yollarının yapacağı hizmetleri çok iyi tanıtıyorum. & 3,35 & 1,08 \\
\hline $\begin{array}{l}\text { X Hava Yollarının sunduğu hizmetlerin toplum tarafından bilindiğini } \\
\text { düşünüyorum. }\end{array}$ & 3,50 & 0,99 \\
\hline X Hava Yolları, havayolları işletmeleri alanında aklıma gelen ilk isimdir. & 4,00 & 1,13 \\
\hline $\begin{array}{l}\text { X Hava Yollarının ürün ve hizmetini satın almadan önce onun ürün ve } \\
\text { hizmetlerinden haberdardım. }\end{array}$ & 3,73 & 0,81 \\
\hline X Hava Yollarını sosyal medyada kolayca tanırım & 3,91 & 0,88 \\
\hline X Hava Yollarının logo ve sembollü hemen dikkatimi çeker. & 3,70 & 0,99 \\
\hline $\begin{array}{l}\text { X Hava Yollarını rakipleri arasında (Bilet satış ofisi, Uçak gibi) ayırt } \\
\text { etmekte zorlanmam. }\end{array}$ & 3,85 & 0,93 \\
\hline $\begin{array}{l}\text { X Hava Yollarının yapmış olduğu faaliyetlerden (reklam, sponsorluk, } \\
\text { sosyal sorumluluk gibi) haberdarım. }\end{array}$ & 3,44 & 1,02 \\
\hline
\end{tabular}


Tablo 2. Cevaplayıcıların Araştırmada Yer Alan Değişkenlerin İfadelerine Karşı Algı ve Tutumları (Devamı)

\begin{tabular}{lcc}
\hline Değişkenler ve İfadeleri & $\begin{array}{c}\text { Aritmetik } \\
\text { Ortalama }\end{array}$ & $\begin{array}{c}\text { Standart } \\
\text { Sapma }\end{array}$ \\
\hline Marka Bağlılığı $(\boldsymbol{\alpha}=\mathbf{0 . 7 8 8 )}$ & & \\
\hline $\begin{array}{l}\text { Rakip havayolu firmalarının düşük fiyat uygulamaları benim rakip } \\
\text { firmaları tercih etmemi sağlar. }\end{array}$ & 2,43 & 1,15 \\
$\begin{array}{l}\text { X Hava Yolları ile bir problem yaşasam dahi başka bir havayolu } \\
\text { işletmesini tercih etmem. }\end{array}$ & 3,40 & 1,08 \\
X Hava Yollarından asla vazgeçmem & 2,95 & 1,00 \\
Daha sonraki uçuşlarımda yine X Hava Yollarını tercih ederim & 3,74 & 1,10 \\
X Hava Yolları havacılık alanında benim seçtiğim en iyi işletmedir. & 3,60 & 0,96 \\
X Hava Yolları ilk sırada tercih edeceğim havayolu markasıdır. & 3,88 & 0,97 \\
X Hava Yollarının sadık bir müşterisi olduğumu düşünüyorum. & 3,18 & 1,11 \\
\hline Algılanan Kalite $(\boldsymbol{\alpha}=\mathbf{0 . 8 2 7 )}$ & & \\
\hline X Hava Yollarının uçuşları kalitelidir & 4,23 & 0,79 \\
X Hava Yollarını güvenilirliği yüksektir. & 4,12 & 0,91 \\
X Hava Yollarının fiyatı kalitesine göre uygundur. & 2,93 & 1,18 \\
X Hava Yolları uçuşlarında kaliteli servis malzemeleri kullanmaktadır. & 3,68 & 0,91 \\
\hline
\end{tabular}

Cevaplayıcıların işletme kaynaklı iletişiminin genel ortalaması 3.87' dir. İşletme kaynaklı ifadelerden "X Hava Yollarının Facebook'taki kurumsal iletişiminden memnunum" ifadesi en yüksek ortalamaya (4.02) sahiptir. İkinci sırada 3.96 oranı ile “X Hava Yollarının Facebook'taki kurumsal iletişimi diğer havayolu işletmeleriyle karşılaştırıldığında onlardan daha iyidir" yer almakta iken işletme kaynaklı iletişime verilmiş en düşük ortalama (3.54) ise "X Hava Yollarının Facebook'taki kurumsal iletişimi benim beklentilerimi karşılamaktadır" ifadesidir.

Cevaplayıcıların müşteri kaynaklı iletişiminin genel ortalaması 3.23'dür. Müşteri kaynaklı ifadelerden "X Hava Yolları hakkında diğer kullanıcılar tarafından sosyal medyada yapılan paylaşımlar diğer havayolları işletmeleriyle karşılaştırıldığında onlardan daha iyidir" ifadesi en yüksek ortalamaya sahiptir (3.56). İkinci sırada 3.25 ortalama ile "X Hava Yolları hakkında diğer kullanıcılar tarafından sosyal medyada yapılan paylaşımlar oldukça ilgi çekicidir" ifadesi yer almaktadır. Verilmiş olan en düşük ortalama ise (3.03) "X Hava Yolları hakkında diğer kullanıcılar tarafından sosyal medyada yapılan paylaşımlar benim beklentilerimi karşılamaktadır" ifadesidir.

Cevaplayıcıların marka farkındalığı genel ortalaması 3.69'dur. Marka farkındalığı ifadelerinden "X Hava Yolları, havayolları işletmeleri alanında aklıma gelen ilk isimdir" ifadesi en yüksek ortalamaya sahiptir (4.00). İkinci sırada ise (3.91) oran ile "X Hava Yollarını sosyal medyada kolayca tanırım" ifadesi yer almaktadır. En düşük ortama ise 3.35 oran ile "X Hava Yollarının yapacağı hizmetleri çok iyi tanitıyorum" ifadesine aittir. 
Cevaplayıcıların marka bağlılı̆̆ı genel ortalaması 3.31'dir. Marka bağl1lığ ifadelerinden "X Hava Yolları ilk sırada tercih edeceğim havayolu markasıdır" ifadesi en yüksek ortalamaya sahiptir (3.88). İkinci sirada ise 3.74 ortama ile "daha sonraki uçuşlarımda yine X Hava Yollarını tercih ederim" ifadesi yer almaktadır. En düşük ortalama ise (2.43) "rakip havayolu firmalarının düşük fiyat uygulamaları benim rakip firmaları tercih etmemi sağlar" ifadesi yer almaktadır.

Cevaplayıcıların algılanan kalite genel ortalaması 3.74'dür. Algılanan kalite değişkenlerinden "X Hava Yollarının uçuşları kalitelidir" ifadesi 4.23 ortalama ile en yüksek ortalamaya sahiptir. İkinci sırada ise 4.12 ortalama ile "X Hava Yollarının güvenilirliği yüksektir" ifadesi yer almaktadır. En düşük ortalamaya sahip ifade ise 2.93 ortalama ile "X Hava Yollarının fiyatı kalitesine göre uygundur" ifadesidir.

\subsubsection{Araştırma Modelinde Yer Alan Ölçeklerin Test Edilmesi}

Araştırma modelinde yer alan kurum kaynaklı iletişim, müşteri kaynaklı iletişim, marka farkındalığı, marka bağlılı̆̆ı, algılanan kalite değişkenlerinin örneğe uygunluğunu test etmek için doğrulayıcı faktör analizi yapılmıştır. Analizin ilk aşamasında ölçeğin uyumluluk değerleri kabul edilebilir sınırlar içerisinde yer almamıştır. Modifikasyonlar incelenerek ki-kare üzerinden en yüksek değişkende modifikasyon öneren değişkenler analiz dışı bırakılmıştır. Yapılan modifikasyon sonrası elde edilen değerler kabul edilebilir değerler içerisinde yer almıştır.

Tablo 3. Modelde Yer Alan Ölçeklerin t değerleri, Standart Katsayıları, R² ve Hata Varyansları

\begin{tabular}{|c|c|c|c|c|}
\hline Değişkenler ve İfadeleri & $\begin{array}{c}\mathbf{t} \\
\text { değerleri } \\
\end{array}$ & $\begin{array}{c}\text { Standart } \\
\text { Katsayıları }\end{array}$ & $\begin{array}{c}\text { Hata } \\
\text { Varyans1 } \\
\end{array}$ & $\mathbf{R}^{2}$ \\
\hline \multicolumn{5}{|l|}{ Kurum Kaynaklı İletişim } \\
\hline $\begin{array}{l}\text { S1: X Hava Yollarının Facebook'taki kurumsal } \\
\text { iletişiminden memnunum. }\end{array}$ & 17,28 & 0,77 & 0,69 & 0,59 \\
\hline $\begin{array}{l}\text { S2: X Hava Yollarının Facebook'taki kurumsal } \\
\text { iletişimi benim beklentilerimi karşılamaktadır }\end{array}$ & 18,69 & 0,82 & 0,54 & 0,66 \\
\hline $\begin{array}{l}\text { S3: X Hava Yollarının Facebook'taki kurumsal } \\
\text { iletişimi oldukça ilgi çekicidir }\end{array}$ & 20,14 & 0,86 & 0,35 & 0,74 \\
\hline $\begin{array}{l}\text { S4: X Hava Yollarının Facebook'taki kurumsal } \\
\text { iletişimi diğer havayolu işletmeleriyle } \\
\text { karşılaştırıldığında onlardan daha iyidir. }\end{array}$ & 14,37 & 0,67 & 0,58 & 0,45 \\
\hline \multicolumn{5}{|l|}{ Müşteri Kaynaklı İletişim } \\
\hline $\begin{array}{l}\text { S5: X Hava Yolları hakkında diğer kullanıcılar } \\
\text { tarafından } \quad \text { sosyal medyada } \\
\text { paylaşımlardan memnunum. }\end{array}$ & 17,58 & 0,81 & 0,34 & 0,65 \\
\hline $\begin{array}{l}\text { S6: X Hava Yolları hakkında diğer kullanıcılar } \\
\text { tarafından sosyal medyada yapılan paylaşımlar } \\
\text { benim beklentilerimi karşılamaktadır. }\end{array}$ & 21,57 & 0,95 & 0,08 & 0,91 \\
\hline $\begin{array}{l}\text { S7: X Hava Yolları hakkında diğer kullanıcılar } \\
\text { tarafından sosyal medyada yapılan paylaşımlar } \\
\text { oldukça ilgi çekicidir. }\end{array}$ & 13,28 & 0,63 & 0,45 & 0,40 \\
\hline
\end{tabular}


Tablo 3. Modelde Yer Alan Ölçeklerin t değerleri, Standart Katsayıları, R² ve Hata Varyansları (Devamı)

\begin{tabular}{|c|c|c|c|c|}
\hline Değişkenler ve İfadeleri & $\begin{array}{c}\mathbf{t} \\
\text { değerleri }\end{array}$ & $\begin{array}{c}\text { Standart } \\
\text { Katsayıları }\end{array}$ & $\begin{array}{c}\text { Hata } \\
\text { Varyansi }\end{array}$ & $\mathbf{R}^{2}$ \\
\hline \multicolumn{5}{|l|}{ Marka Farkındalı̆̆ı } \\
\hline $\begin{array}{l}\text { S9: X Hava Yollarının yapacağı hizmetleri çok iyi } \\
\text { taniyorum. }\end{array}$ & 17,31 & 0,88 & 0,27 & 0,77 \\
\hline $\begin{array}{l}\text { S11: X Hava Yolları, havayolları işletmeleri } \\
\text { alanında aklıma gelen ilk isimdir. }\end{array}$ & 13,54 & 0,69 & 0,67 & 0,47 \\
\hline $\begin{array}{l}\text { S12: X Hava Yollarını ürün ve hizmetlerini satın } \\
\text { almadan önce onun ürün ve hizmetlerinden } \\
\text { haberdarım }\end{array}$ & 6,93 & 0,37 & 0,58 & 0,14 \\
\hline $\begin{array}{l}\text { S13: X Hava Yollarını sosyal medyada kolayca } \\
\text { tanırım. }\end{array}$ & 11,87 & 0,60 & 0,49 & 0,37 \\
\hline \multicolumn{5}{|l|}{ Marka Bağlılı̆̆1 } \\
\hline $\begin{array}{l}\text { S17: Rakip havayolu firmalarının düşük fiyat } \\
\text { uygulamaları benim rakip firmaları tercih etmemi } \\
\text { sağlar. }\end{array}$ & 3,18 & 0,18 & 1,28 & 0,04 \\
\hline $\begin{array}{l}\text { S18: X Hava Yolları ile problem yaşasam dahi } \\
\text { başka bir hava yolu işletmesini tercih etmem. }\end{array}$ & 4,14 & 0,39 & 1,01 & 0,15 \\
\hline S19: X Hava Yollarından asla vazgeçmem. & 14,94 & 0,75 & 0,44 & 0,56 \\
\hline $\begin{array}{l}\text { S20: Daha sonraki uçuşlarımda yine } X \text { Hava } \\
\text { Yollarını tercih ederim }\end{array}$ & 12,90 & 0,65 & 0,71 & 0,42 \\
\hline $\begin{array}{l}\text { S21: X Hava Yolları havacılık alanında benim } \\
\text { seçtiğim en iyi işletmedir. }\end{array}$ & 12,86 & 0,66 & 0,53 & 0,43 \\
\hline $\begin{array}{l}\text { S22: Türk Hava Yolları ilk sırada tercih edeceğim } \\
\text { havayolu markasıdır. }\end{array}$ & 10,60 & 0,56 & 0,65 & 0,31 \\
\hline \multicolumn{5}{|l|}{ Algılanan Kalite } \\
\hline S24: X Hava Yolları uçuşları kalitelidir. & 5,60 & 0,55 & 0,41 & 0,35 \\
\hline S25: X Hava Yollarının güvenilirliği yüksektir & 5,88 & 0,77 & 0,34 & 0,60 \\
\hline $\begin{array}{l}\text { S27: X Hava Yolları uçuşlarında kaliteli servis } \\
\text { malzemeleri kullanmaktadır. }\end{array}$ & 3,87 & 0,24 & 1,32 & 0,06 \\
\hline
\end{tabular}

Modifikasyonlar sonrasında müşteri kaynaklı marka iletişiminden 1, marka farkındalığından 4, algılanan kaliteden 4, marka bağlılığından 1, mevcut satın alımdan 1 ifade analizde çıkarılmıştır. Tablo 3 'de araştırma modelinde yer alan ölçeklere ait değişkenlerin $t$ değerleri, standart katsayılar, $R^{2}$ ve hata varyanslarına ait değerler verilmiştir.

\subsubsection{Araştırma Modelinin Testi}

Araştırma modelinin testi için yapısal eşitlik modelleme (path analizi) kullanılmıştır. Path analizinde, işletme ve müşteri kaynaklı iletişiminin, marka farkındalığına, marka bağlılığına ve algılanan kaliteye olan etkisi ölçümlenmeye çalışılmıştır. Yapılan ilk analiz sonuçlarında uyum değerlerinin istatistik bakımdan kabul edilebilir düzeyde olmadığı görülmüştür. Bu analizin uyum değerleri Tablo $4^{\prime}$ de gösterilmiştir. 
Tablo 4. Modelin Modifikasyon Öncesi ve Sonrası Uyumluluk İndeks Değerleri

\begin{tabular}{lcccc}
\hline \multicolumn{1}{c}{$\begin{array}{c}\text { Uyum } \\
\text { Kriterleri }\end{array}$} & $\begin{array}{c}\text { Modifikasyon } \\
\text { Öncesi Uyum } \\
\text { Değerleri }\end{array}$ & $\begin{array}{c}\text { Modifikasyon Sonrasi } \\
\text { Uyum Değerleri }\end{array}$ & $\begin{array}{c}\text { Kabul Edilebilir } \\
\text { Uyum Değerleri }{ }^{1}\end{array}$ & $\begin{array}{c}\text { Mükemmel Uyum } \\
\text { Değerleri }^{2}\end{array}$ \\
\hline Ki-Kare(X2) & 797.76 & 79.30 & 2 sd $<\mathrm{x}^{2} \leq 3 \mathrm{sd}$ & $0<\mathrm{x}^{2} \leq 2 \mathrm{sd}$ \\
p Değeri & 0.00000 & 0.15210 & $0.01<\mathrm{p} \leq 0,05$ & $0.05<\mathrm{p} \leq 1,00$ \\
Serbestlik & & & & \\
Derecesi (Sd) & 110 & & & \\
Ki-Kare-Sd & 7.25 & 2,64 & $2 \leq \mathrm{x}^{2} / \mathrm{sd} \leq 3$ & $0 \leq \mathrm{x}^{2} / \mathrm{sd} \leq 2$ \\
RMSEA & 0.125 & 0,074 & $0.05 \leq \mathrm{RMSEA} \leq 0.08$ & $0 \leq \mathrm{RMSEA} \leq 0.05$ \\
SRMR & 0.064 & 0,043 & $0.05 \leq \mathrm{RMSR} \leq 0.10$ & $0 \leq \mathrm{SRMR} \leq 0.05$ \\
NFI & 0.75 & 0,92 & $0.95 \leq \mathrm{NFI} \leq 0.95$ & $0.95 \leq \mathrm{NFI} \leq 1.00$ \\
NNFI & 0.72 & 0,92 & $0.90 \leq \mathrm{NFI} \leq 0.97$ & $0.97 \leq \mathrm{NNFI} \leq 1.00$ \\
CFI & 0.77 & 0,95 & $0.95 \leq \mathrm{CFI} \leq 0.97$ & $0.97 \leq \mathrm{CFI} \leq 1.00$ \\
GFI & 0.81 & 0.96 & $0.90 \leq \mathrm{GFI} \leq 0.95$ & $0.95 \leq \mathrm{GFI} \leq 1.00$ \\
AGFI & 0.74 & 0.92 & $0.85 \leq \mathrm{AGFI} \leq 0.90$ & $0.95 \leq \mathrm{AGFI} \leq 1.00$ \\
IFI & 0.78 & 0.95 & $0.90 \leq \mathrm{IFI} \leq 0.95$ & $0.95 \leq \mathrm{IFI} \leq 1.00$ \\
\hline
\end{tabular}

Sonuçlara göre 797.76 ki-kare değeri ve 110 serbestlik derecesinin birbirine oranı 7.75 olup, önerilen değerler arasında olmaması nedeniyle kabul edilebilir düzeyde olmadığı görülmektedir. Uyum indeksi (GFI)'nın değeri 0.81olup, 0.90'dan küçük olduğu için kabul edilebilir düzeyde değildir. Düzeltilmiş iyilik indeksi (AGFI) 0.74 olup, önerilen 0.85 ' den düşük olduğu için kabul edilebilir düzeyde değildir. SRMR değeri 0.064 'dır. RMSEA değeri 0.125 olup, istatistiki olarak önerilen 0.08 değerinden büyük olduğu için bu değer modelin kabul edilebilirliği için yeterli değildir. Artmalı uyum indeksi (CFI)'nin değeri 0.77 olup, 0.95 'ten küçük olduğu için kabul edilebilir düzeyde değildir. Bu değerlere göre, araştırma modeli kabul edilebilirlik için yeterli değildir

Modifikasyonlar incelenerek Ki-Kare üzerinden yüksek değerde modifikasyon öneren değişkenler analiz dışı bırakılmıştır. Yapılan modifikasyonlar sonrasında elde edilen indeks değerleri, kabul edilebilir değerler içerisinde yer almıştır. Modifikasyon sonrası uyum indeks değerlerinin kabul edilebilir düzeyde olduğu belirlenmiştir. Elde edilen uyum indeks değerleri yukarıdaki tabloda görülmektedir. Tabloya göre araştırma için oluşturulan modelin incelenen sektör ve saha açısından uygun olduğu ifade edilebilir.

Yapılan yapısal eşitlik modeli analizine göre, model için önerilen modifikasyonlar yapılmış ve istatistiki bakımdan uygun olmayan değişkenler elendikten sonra kalan değişkenler ve değişkenlerin $t$ değerleri, standart katsayılar, $\mathrm{R}^{2}$ ve hata varyanslarına ait değerleri Tablo 5'da gösterilmiştir. Bu sonuçlara göre $\mathrm{H}_{1}, \mathrm{H}_{2}$

1 Kabul Edilebilir Uyum Değerleri: $2 \mathrm{df} \leq \chi^{2} \leq 3 \mathrm{df}, \quad 0.01 \leq \mathrm{p} \leq 0.05, \quad 2 \leq \chi^{2} \quad / \mathrm{df} \leq 3, \quad 0.05 \leq \mathrm{RMSEA} \leq 0.08$, $0.05 \leq \mathrm{SRMR} \leq 0.10, \quad 0.90 \leq \mathrm{NFI} \leq 0.95, \quad 0.95 \leq \mathrm{NNFI} \leq 0.97, \quad 0.95 \leq \mathrm{CFI} \leq 0.97, \quad 0.90 \leq \mathrm{GFI} \leq 0.95, \quad 0.85 \leq \mathrm{AGFI} \leq 0.90$, $0.90 \leq \mathrm{IFI} \leq 0.95$ (Schermelleh-Engel ve diğg., 2003, s.52).

${ }^{2}$ Mükemmel Uyum Değerleri: $0 \leq \chi^{2} \leq 2 \mathrm{df}, 0.05<\mathrm{p} \leq 1.00,0 \leq \chi^{2} / \mathrm{df} \leq 2,0 \leq \mathrm{RMSEA} \leq 0.05,0 \leq \mathrm{SRMR} \leq 0.05$, $0.95 \leq \mathrm{NFI} \leq 1.00,0.97 \leq \mathrm{NNFI} \leq 1.00,0.97 \leq \mathrm{CFI} \leq 1.00,0.95 \leq \mathrm{GFI} \leq 1.00,0.90 \leq \mathrm{AGFI} \leq 1.00,0.95 \leq \mathrm{IFI} \leq 1.00$ (SchermellehEngel ve diğ., 2003, s.52). 
ve $\mathrm{H}_{7}$ hipotezleri kabul edilmiş olup $\mathrm{H}_{3}, \mathrm{H}_{4}, \mathrm{H}_{5}, \mathrm{H}_{6}$ ve $\mathrm{H}_{8}$ hipotezleri ise reddedilmiştir.

Tablo 5. Modelde Yer Alan Değişkenlerin t değerleri, Standart Katsayıları, R² ve Hata Varyansları

\begin{tabular}{|c|c|c|c|c|}
\hline Değişkenler & $t$ değerleri & $\begin{array}{l}\text { Standart } \\
\text { Katsayıları }\end{array}$ & $\mathbf{R}^{2}$ & $\begin{array}{c}\text { Hata } \\
\text { Varyans }\end{array}$ \\
\hline \multicolumn{5}{|l|}{ Kurum Kaynaklı İletişim } \\
\hline $\begin{array}{l}\text { S2: X hava yollarının Facebook'taki kurumsal } \\
\text { iletişimi benim beklentilerimi karşılamaktadır. }\end{array}$ & 17,49 & 0,83 & 0,69 & 0,50 \\
\hline $\begin{array}{l}\text { S4: X hava yollarının Facebook'taki kurumsal } \\
\text { iletişimi diğer havayolu işletmeleriyle karşılaştığında } \\
\text { onlardan daha iyidir. }\end{array}$ & 17,01 & 0,68 & 0,46 & 0,57 \\
\hline \multicolumn{5}{|l|}{ Marka Farkındalığı } \\
\hline $\begin{array}{l}\text { S9: X hava yollarının yapacağı hizmetleri çok iyi } \\
\text { tanitıyorum }\end{array}$ & 8,97 & 0,82 & 0,68 & 0,38 \\
\hline $\begin{array}{l}\text { S11: X hava yolları, havayolları işletmeleri alanında } \\
\text { aklıma gelen ilk isimdir. }\end{array}$ & 13,77 & 0,69 & 0,47 & 0,68 \\
\hline $\begin{array}{l}\text { S12: X hava yollarının ürün ve hizmetlerini satın } \\
\text { almadan önce onun ürün ve hizmetlerinden } \\
\text { haberdarım }\end{array}$ & 8,36 & 0,44 & 0,19 & 0,54 \\
\hline S13: X hava yolları sosyal medyada kolayca tanırım & 12,78 & 0,04 & 0,41 & 0,46 \\
\hline \multicolumn{5}{|l|}{ Marka Bağlılığ } \\
\hline $\begin{array}{l}\text { S17: rakip hava yolu firmalarının düşük fiyat } \\
\text { uygulamaları benim rakip firmaları tercih etmemi } \\
\text { sağlar }\end{array}$ & 14,02 & 0,16 & 0,03 & 1,29 \\
\hline $\begin{array}{l}\text { S18: } X \text { hava yolları ile bir problem yaşasam dahi } \\
\text { başka bir havayolu işletmesini tercih etmem }\end{array}$ & 2,64 & 0,41 & 0,17 & 0,99 \\
\hline $\begin{array}{l}\text { S22: } X \text { hava yolları ilk sırada tercih edeceğim } \\
\text { havayolu markasıdır. }\end{array}$ & 2,72 & 0,56 & 0,32 & 0,65 \\
\hline
\end{tabular}

\section{SONUÇ VE ÖNERILLER}

İşletmelerin sosyal medya kanalları üzerinden müşterileri ile kurmuş oldukları iletişimin marka bağlılığına etkisini ölçmeyi amaçlayan bu araştırmada şu sonuçlar elde edilmiştir. Cevaplayıcıların çoğu işletmelerin sosyal medya hesapları üzerinden gerçekleştirmiş oldukları iletişimde markaya olan farkındalığı oluşturduğunu belirtmiştir. $\mathrm{Bu}$, markaya olan bağl1lığı etkilemiştir. Bu bağlamda ele alınan sorularda işletmenin gerçekleştirmiş olduğu kurumsal iletişimin cevaplayıcıların beklentilerini karşıladığı tespit edilmiştir. Bununla beraber ele alınan işletmenin kurumsal iletişiminden memnun olan cevaplayıcıların, markanın hemen hemen tüm faaliyetlerinden haberdar bir durumda olduğu tespit edilmiştir. Araştırma modelinde yer alan etkileşimlerin gerçekleştiği ve araştırma modelinin incelenen saha ve sektör için geçerli olduğu tespit edilmiştir. Buna göre kurumların gerçekleştirmiş olduğu iletişim faaliyetleri arttıkça marka farkındalığ 1 artacak, artan marka farkındalığı ise markaya olan bağlılı̆̆1 güçlendirecektir. Araştırmada elde edilen bulgulara göre şu önerilerde bulunulabilir. 
Öncelikle işletmeler rekabet piyasasında etkinliklerini daha fazla arttırmak için ve farkındalık oluşturmak için iletişim çalışmalarına önem vermelidir. Verilen bu önemin zaman içerisinde işletmeye olan bağlllığ1 arttıracağı göz önünde tutularak iletişim çalışmaları yapılmalıdır.

Bu bağlamda işletmeler marka bağlılığını oluşturmak için iletişim çalışmaları, reklam, sponsorluk v.b faaliyetlere önem vermeli ve bu doğrultuda hareket etmelidir.

\section{KAYNAKÇA}

Aaker, D.A. (1996). Measuring Brand Equity Across Products And Markets, CA Management Review, 38(3): 102-120.

Bambauer-Sachse, S. ve Mangold, S. (2011). Brand Equity Dilution Through Negative Online Word-Of-Mouth Communication, Journal of Retailing and Consumer Services, 18(1): 38-45.

Bazanbaş, Ş. (2013). Algılanan Kalite İle Müşteri Tatmini Arasındaki İlişki; Filtre Kullanıcılar Üzerine Yapılan Ampirik Bir Çalışma, Akademik Bakış Dergisi, 4(4): 10-25.

Brodie, R.J., Ilic, A., Juric, B. ve Hollebeek, L. (2013). Consumer Engagement In A Virtual Brand Community: An Exploratory Analysis, Journal of Business Research, 66(8): 105-114.

Bruhn, M., Schoenmueller, V. ve Schäfer, D.B. (2012). Are Social Media Replacing Traditional Media In Terms Of Brand Equity Creation?, Management Research Review, 35(9): 770-790.

Can, P. (2016). Marka Deneyimi, Hedonik Duygular ve Algılanan Reklam Harcamalarının Marka Değeri Boyutlarına Etkisi Üzerine Fast Food Sektöründe Bir Araştırma. Uluslararası Yönetim İktisat ve İşletme Dergisi, 12(30): 121-143. (http://dx.doi.org/10.17130/ijmeb.20163024228)

Can, P. ve Çetin, İ. (2017). A Research on the Comparison of the Effect of Benefits Obtained from Social Media Marketing to Brand Commitment in Terms of Domestic and Foreign Consumers. International Business Research, 10(2): 29-42. (doi.org/10.5539/ibr.v10n2p29)

Christodoulides, G. ve de Chernatony, L. (2010). Consumer-Based Brand Equity Conceptualisation And Measurement: A Literature Review, International Journal of Market Research, 52(1): 43-65.

İnceoğlu, M. (2011). Tutum Alg̨ İletişimi, Siyasal Yayınları: Ankara.

Gil, R.B., Andrés, E.F. ve Salinas, E.M. (2007). Family As A Source Of Consumer-Based Brand Equity, Journal of Product \& Brand Management, 16(3): 188-199.

Ha, H.Y., John, J., Janda, S. ve Muthaly, S. (2011). The Effects Of Advertising Spending On Brand Loyalty İn Services, European Journal of Marketing, 45(4): 673-691.

Kaplan, A.M. ve Haenlein, M. (2012). The Britney Spears Universe: Social Media And Viral Marketing At İts Best, Business Horizons, 55(1): 27-31.

Keller, K.L. (2009). Building Strong Brands İn A Modern Marketing Communications Environment, Journal of Marketing Communications, 15(2-3): 139-155.

Kırdal, Y. (2005). Marka Stratejilerinin Oluşturulması: Cola Cola Örneği, Kırgız-Manas Üniversitesi, Sosyal Bilimler Dergisi, 3(4): 20-30.

Li, C. ve Bernoff, J. (2011). Groundswell: Winning in a World Transformed by Social Technologies, Harvard Business Review Press:Boston. 
Mackay, M.M. (2001). Evaluation Of Brand Equity Measures: Further Empirical Results, Journal of Product \& Brand Management, 10(1): 38-51.

Muñiz, A.M. ve Schau, H.J. (2007). Vigilante Marketing And Consumer-Created Communications, Journal of Advertising, 36(3): 35-50.

Palmatier, R.W., Scheer, L.K. ve Stennkamp, J.B.E.M. (2007). Customer Loyalty To Whom? Managing The Benefits And Risks Of Salesperson-Owned Loyalty, Journal of Marketing Research, 44(2): 185-199.

Pira, A., Kocabaş, F. ve Yeniçeri, M. (2005). Küresel Pazarda Marka Yönetimi Ve Halkla İlişkiler, Dönence Yayınları: İstanbul.

Raggio, R.D. ve Leone, R.P. (2007). The Theoretical Separation Of Brand Equity And Brand Value: Managerial Implications For Strategic Planning, Journal of Brand Management, 14(5): 380-395.

Schivinski, B. ve Dabrowski, D. (2014). The Impact of Brand Communication on Brand Equity Through Facebook. Journal of Research in Interactive Marketing, 9(1): 31-53.

Schermelleh-Engel, K., Moosbrugger, H. ve Müler, H. (2003). Evaluating the Fit of Structural Equation Models: Tests of Significance and Descriptive Goodness-of-Fiteasures. Methods of Psychological Research, 8: 23-74.

Shum, M. (2004). Does Advertising Overcome Brand Loyalty? Evidence From The BreakfastCereals Market, Journal of Economics \& Management Strategy, 13(2): 241-272.

Taşkın, E. (2005). Müşteri İlişkileri Ĕ̆gitimi, Papatya Yayıncılık: İstanbul.

Villarejo-Ramos, A.F. ve Sánchez-Franco, M.J. (2005). The Impact Of Marketing Communication And Price Promotion On Brand Equity, Journal of Brand Management, 12(6): 431-444.

Wang, W.T. ve Li, H.M. (2012). Factors Influencing Mobile Services Adoption: A Brand-Equity Perspective, Internet Research, 22(2): 142-179. 